\title{
エアージェットノズルによる高速紡糸について
}

\author{
東京工業大学工学部清 水二 郎 \\ 岥皋大学工業短期大学部渡辺明 \\ 東京工業大学工学部鳥海浩一郎
}

\section{THE HIGH SPEED SPINNING BY USING AN AIR JET NOZZLE}

\author{
By Jiro Shimizu, * Akira Watanabe** and Koichiro Toriumi* \\ *(Tokyo Institute of Technology, Ookayama, Meguro-ku, Tokyo, Japan) \\ **(Junior Technical College, Gifu University, Kakamigahara City, \\ Gifu Prefecture, Japan)
}

\begin{abstract}
This report deals with an experimental investigation on the drawing method of the molten polymer of P.P. by means of an air jet nozzle. Fig. I is a structural diagram of the air jet nozzle, which was designed in such a way that the jet air may reach the sonic velocity at nozzle pressures above $2.18 \mathrm{~kg} / \mathrm{cm}^{2}$. The air flow below the outlet of the jet nozzle was observed by schlieren method in the form of shock waves as shown in Fig. 2 . In the drawing process, considering the force balance on the running yarn at the point of jet nozzle, the fineness of the yarn should possess a limiting value. Fig.9 shows the calculated values of the limiting fineness at various positions of the jet nozzle from the spinneret and at various air pressures in the nozzle. Fig. 10 shows the results obtained from the experimental values. These values are compared in Table 1. The load-elongation curves of the yarns are shown in Figs. 13-16, and their birefringenes $(\Delta n)$ in Figs. 17 and 18 .
\end{abstract}

(Received September 8, 1973)

\section{1. 緒 言}

溶融ポリマーを細化すると同時に，その配向をも高力 るために，高速紡系の技術が検討開発されている。この 手段としては，高速回転するローラにより延伸または巻 取る方法と，高速空気を用い非接触の状熊で延伸捕捉寸 る方法とがある。とくに，後者に関しては，高速気流上 り発生する乱流状態を利用し，㵶維をみだし捕捉する方 法を工夫することにより：シートを形成し不織布をつく るダイレクト・フォフリケーション法（スパンボンド） などが開発されつつある。本報は，空気延伸紡系に関寸 る高速細化に㧍けるものであり，高速細化時に括ける張 力の発生機構について，実験的に検討したものである。 細化時に扔ける架気抵抗力に閶しては，ポリプロピレン の容融紡系を対象として, 走行速度 $1000 \mathrm{~m} / \mathrm{min}$ 以下で 詳細な報告が佐野によって行なわれている 。ここでは， 走行糸の相対速度が $800 \mathrm{~m} / \mathrm{min}$ を越えると，巻取り点 での張力の的 50 \%が空気抵抗力によることを実鈳的に明 らかにしている。紡采時における複屈折的な配向上，張 力の依存性に関して标すでに多くの報告があるが，ポリ プロピレンの客融紡系については，著者によっても検討 されている゙。また，高速紡系に関しては金綱らにより， とくに急冷時の効果が報告されているき。

本報では延伸細化機構に対する音速域での高速気流を
発生するジェット・ノズルとジェット流による張力の侇 存性についてまず揄討した。現在までの研究により， 亚音速域以下では，张力は空気速度により定まることが 明らかにされているが, 音速域での張力の依存性は明ら かではない。本報ではまた, 数 $1000 \mathrm{~m} / \mathrm{min}$ の紡系速度 による等気抵抗力を寒験的に検討し，あわせてそれによ る延伸機满と种化の限界拉よびその効果について言及す 万。

\section{2. 音速域ての張力依存性}

ジェット・ノズルは，先細ノズルを取付けた高生タン クより成り立っていて，その構造はFig.1に示す上らで ある。压力は，大型コンプレッサーによって連続的に 10 $\mathrm{kg} / \mathrm{cm}^{2}$ までかけられる。このシェット・ノズルは, 紡 米孔の下方 1〜2mの間に設置され，瀻踓はノズ中央 の $0.7 \mathrm{~mm} \varphi$ の細管より、ジェット流中に放出されるよう に設䛨されている。このよらなリザーバーを有する先細， ズルの出口速度については，先細ノズルの理論式 (1) 式 によって,つぎのように与えられている”。

$$
\frac{u_{e}}{a_{0}}=\sqrt{\frac{2}{K-1}\left\{1-\left(\frac{P_{b}}{P_{0}}\right)^{\frac{K-1}{K}}\right\}}
$$

$u_{e}$ ：出口速度 $(\mathrm{m} / \mathrm{s}) \quad a_{0}$; 音速 $(\mathrm{m} / \mathrm{s}) K$; 比熱比

$P_{b}$ : 大気压 $\left(\mathrm{kg} / \mathrm{cm}^{2}\right) P_{0}$ ；タンク内の开力 $\left(\mathrm{kg} / \mathrm{cm}^{2}\right)$ 出口速度が音速に達した場合, $u_{e} / a_{0}=1, P_{b}=1, K=$ 


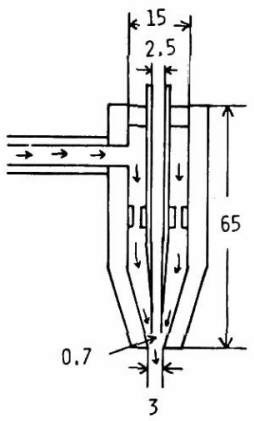

Fig.1 The structure of the air jet nozzle (dim.: mm)

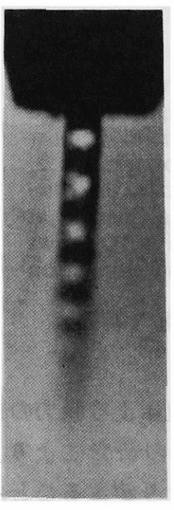

$6 \mathrm{~kg} / \mathrm{cm}^{2}$

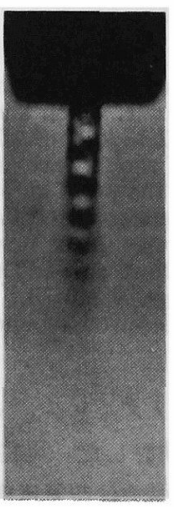

$4 \mathrm{~kg} / \mathrm{cm}^{2}$

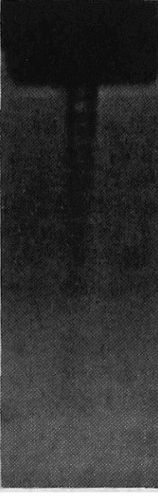

$2 \mathrm{~kg} / \mathrm{cm}^{2}$
Fig. 2 The photographs taken by schlieren method showing the air flow below the jet nozzle

1.4 とすると, $P_{0}=2.18 \mathrm{~kg} / \mathrm{cm}^{2}$ となる。したがって， 高圧源の圧力を $2.18 \mathrm{~kg} / \mathrm{cm}^{2}$ 以上にした場合, ジェット 流は音速に達する。このジェット流が音速域に達した場 合，ノズル出ロからジッット流中に衝撃縞が発生する。 この状態をシュリーレン法によって可視化すると Fig. 2 のような衝撃縞が観察された。この衝撃稿は, 高圧源の 圧力により変化する。すなわち, 衝撃縞の長さは, 圧力 $6 \mathrm{~kg} / \mathrm{cm}^{2}$ で $3.2 \mathrm{~cm}, 4 \mathrm{~kg} / \mathrm{cm}^{2}$ で $2.3 \mathrm{~cm}, 2 \mathrm{~kg} / \mathrm{cm}^{2}$ で $1.8 \mathrm{~cm}$ であり，幅は圧力の増加にともなってわずかに ふくらむが，いづれも約 $3 \mathrm{~mm}$ 前後でジェットの出口の 径 $(3 \mathrm{~mm} \varphi)$ にほぼ等しく, また縞間隔についてもわず かしか增加せず約 $2.2 \sim 5.0 \mathrm{~mm}$ の範囲である。

ジェット流による繊維に付与する張力を検討するため に,ナイロン・テグス $(534 \mu)$ をノズル中に通し，上端 を $u$ ゲージに固定し, ジェットノズルの出口からの系長 $(l)$ と圧力 $(P)$ を変化させて, その時発生する張力 $(F)$ を測定した。その結果をFig. 3 に示す。張力の実測結果 によると, 試長数 $\mathrm{cm}$ のところに極大值があり, 音速域
後に存在する乱流域でかなり高速の気流がなお数 $10 \mathrm{~cm}$ のところまで流れる。しかしながら, 張力 $(F)$ は王力 $(P)$ の大きさに比例し，系長 $(l)$ に対してはある長さ (数 $\mathrm{cm}$ ) 以上では変化しないことがわかった。シュリーレン法の 観察結果とこの張力の結果より, 張力の発生に奇与する のは衝撃縞の長さの範囲内であり, それ以後の乱流域中 に介在する縬維長は張力に大きな影響を与えないものと 思われる。

つぎに, 㵶維の太さ $(R)$ と王力を変えたときの張力の 測定結果を Fig. 4 に示す。これより, 㵶維の太さに対し て, 張力は直線的に増加することがわかる。一般に走行 系の張力が表面積により定まるところから, 張力を表面 積すなわち直径で割って， $\log P$ に対してプロットする と Fig.5のようになる。その関係式は， $F / 2 R=\alpha \log P$ + $\beta$ で表わされるが，張力が表面積により一義的に決ま らないことを示している。すなわち， $\alpha$ は太さにはあま り関係せず約 0.006 の一定值をとるが， $\beta$ は太さによっ て異なり，その値は図中に示すようである。

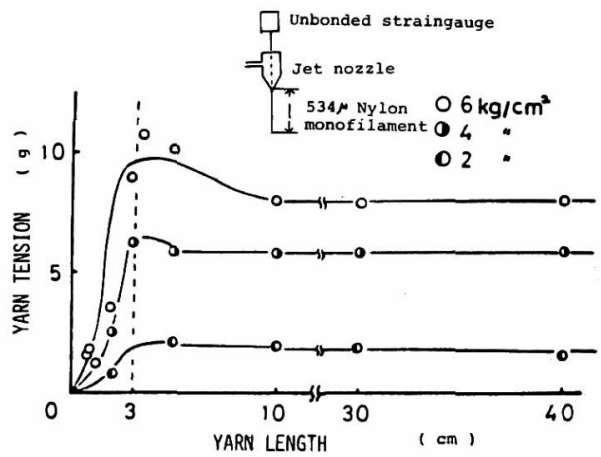

Fig.3 The relationship between the tension formed from the air jet nozzle on the yarn and the yarn length $(l)$ below the jet nozzle

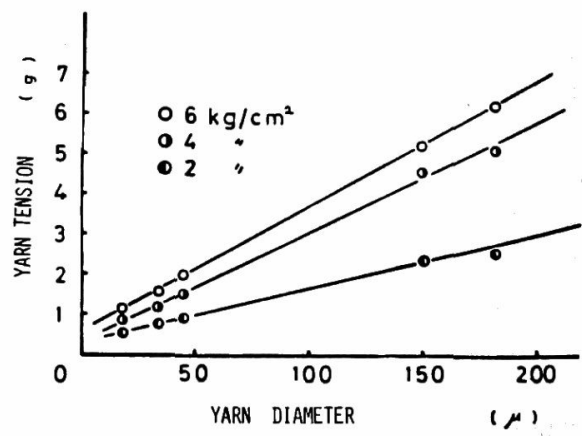

Fig.4 The relationship between the tension from the air jet nozzle on the yarn and the yarn diameters 


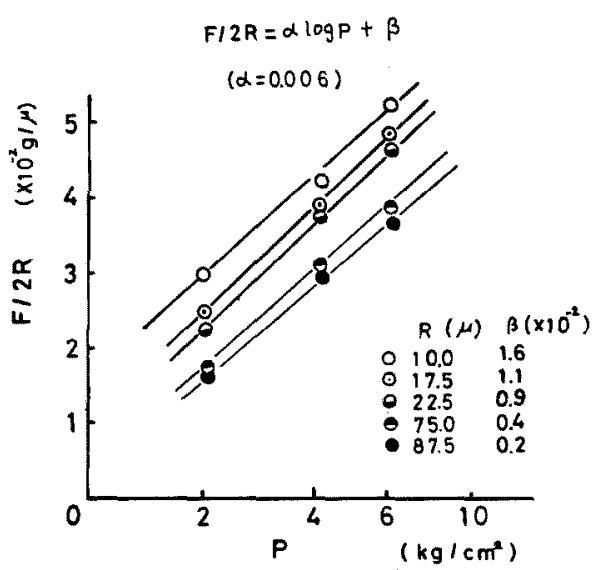

Fig.5 The relationship between the tensional force $(F)$ divided by the yam diameter $(2 R)$ and the pressure $(P)$ inside the jet nozzle

\section{3. 延伸 譏構}

紡系孔からジェット・ノズルまでに执いて，延伸は完 了する。この祭，織維はポリマ一の変形抗力，慣性力， 自重㧍よび空気抵抗力に対する送り出し張力(ジェット ・ノズルによって発生する張力)との力平衡によって定 まる。シェット・ノズルの位置に枋いて，紡系中の繊維 に動らく力の平衡について考えると、つぎのようになる。

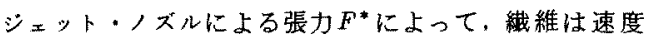
$v_{f}$ で送り出され，ポリマーの変形抗力をS，紡禾孔からシ エット・ノズルまでの空気抵抗力を $f$, 䢂維の慣性力を

\section{$T$ ，自重を $g$ とすると，(2) 式の関保が成立する。}

$F^{*}=S+f-T-g$

紡系中の織維に動らく空気抵抗力 $(f)$ の大きを、つ

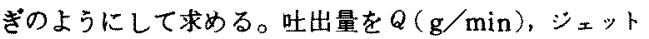
・ノズル゙の織維の速度を $v_{f}(\mathrm{~m} / \mathrm{sec})$, 織維の半径を $R(\mathrm{~m})$ ，ポリーの比重をのとする。これより(3) 式の 関保が成立する。

$$
Q=60 \pi R^{2} v_{f} \rho
$$

○は温度によって定まるが，溶螼での温度を保つもの として，後述するポリプロピレンの平均比重を 0.8 とする。

(3) 式を $v_{f}$ にいてまとめると(3)'式となる。

$$
v_{f}=6.63 \times 10^{-8} Q / R^{2}
$$

(3) 式のQk後述する実験条件の $0.485 \mathrm{~g} / \mathrm{min}$ を代入 して， $v_{f}$ と Rの関係を求めると Fig.6(a)のようになる。 これより，紡来速度と半径との間には2次的な関俰があ ることがわかる。紻維は紡系孔を出ると急激に紐化する。 そこで, 紡系孔とジェット・ノズルまでの長さ $(L)$ の間 のレイノルズ数 $\left(R_{e w}\right)$ は，緎維の半径を一定と考えると， (4) 式で表わされる。

$$
R_{e w}=2 R\left(v_{f}-v_{a}\right) \rho_{a} / \mu_{a}
$$

空気密度 $\left(\rho_{a}\right)$ t $0.83 \mathrm{~kg} / \mathrm{m}^{3}$ ，悬断粘度 $\left(\mu_{a}\right)$ を $2.38 \times$ $10^{-6} \mathrm{~kg} / \mathrm{m} \cdot \mathrm{sec}$ ，空気速度(紡系孔とジェット・ズル 間) $\left(v_{a}\right)$ をととし， $v_{f}$ に(3)'式を代入してRewを表わ すと $(4)^{\prime}$ 式となる。

$$
R_{e} w=4.62 \times 10^{-4} Q / R
$$

$Q=0.485 \mathrm{~g} / \mathrm{min}$ として，(4) 式をFig.6 (b) に示す。

われわれの実験では， $R(\mathrm{~m})$ が $8 \sim 20 \times 10^{-6}$ の範囲 で，Rewにすると的30〜10となり，これは佐野の実験

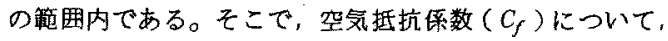
佐野の吏験式である(5) 式を用いる1。

$$
C_{f}=0.68 R e w^{-0 . s}
$$

（5）式に(4)'式を代入して $C_{f}$ を表わすと（5)'式となる。 $C_{f}=332(R / Q)^{0.8}$

$Q=0.485 \mathrm{~g} / \mathrm{min}$ として，(5)'式をFig.6(c)に示す。

つぎに，紡系孔とシェット・ノズル間の空気抵抗力 $(f)$

は (6) 式で表わされる。

$$
f=2 \pi R L\left(v_{f}-v_{a}\right)^{2} C_{f} 10^{8} / 9.8
$$

$v_{a}=0$ とし， $v_{f}$ と $C_{f}$ にそれぞれ $(3)^{\prime}$ 式と (5)'式を代入

して， $f$ 表わすと $(6)^{\prime}$ 式となる。

$$
f=9.35 \times 10^{-12} L Q^{1.2} / R^{2.3}
$$

(6)'式をFig.6(d)に示す。これより, 紡糸速度が增加 して，鐵度 $(R)$ が小さくなるにもかかからず，空気抵抗 力は 2 次曲線的に増加寸ることがわかる。また，Lが小 さいほど，すなわちシェット・ノズルを紡系孔に近づけ るほど，空気抵抗力は小さくなことを示している。

つぎに，織維が $v_{f}(\mathrm{~m} / \mathrm{sec})$ 速度でジェット・/ス ルを通過するときの慣性力 $T(\mathrm{~g})$ は（7) 式によって与 えられる。

$$
T=Q \cdot v_{f} \times 1.7 \times 10^{-s}
$$

7 式で与えられる $T$ の值は，空気抵抗力 $(f)$ に比べて小 さく，Fig.6(d)の破線は $(f-T)$ の值をプロットした ものである。

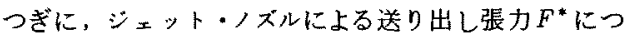
いて述べる。F゙を正確に測定することは困難でるので， つぎの2つの場合について考察する。

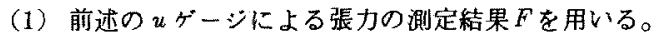
この場合，蟣維は静止しているので， $F^{*} に$ に比べて小さい はずである。しかし，ジット流の速度（音速）は，擮 維の速度 $\left(v_{f}\right)$ よりはるかに大きい（4５倍）ので，F $\div F^{*}$ と考光られる。

（2）紡絲ロからシェット・ノズルまでの距離を一定に して、シェット・ノズルの上端に掂いて測定した紡系中 の張力 $F^{* \prime}$ を用いる。(測定器は, 金井工機製 : テンシ ョン・チェッカー)この場合, この張力 $\left(F^{* \prime}\right)$ 注張力測 定点とジット・ノズル出口までの空気抵抗力を含んだ 

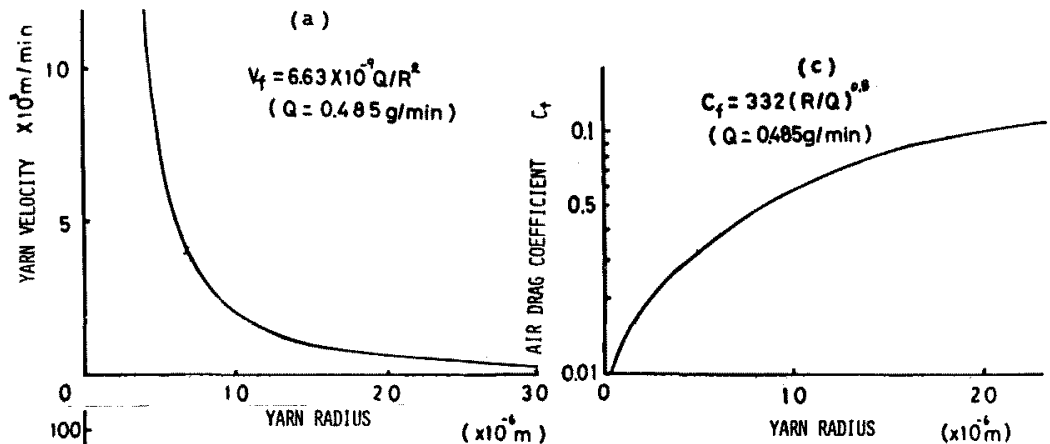

(b)
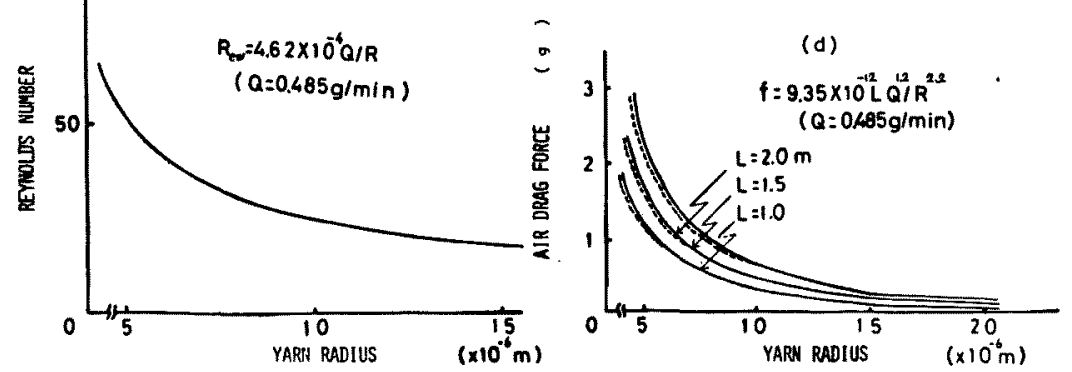

Fig.6 The curves of yarn velocity $\left(v_{f}\right)(\mathrm{a})$, Reynolds number $\left(R_{e w}\right)$ (b), air drag coefficient $\left(c_{f}\right)(\mathrm{c})$, and air drag force $(f)$ plotted against fineness $(R)(\mathrm{d})$

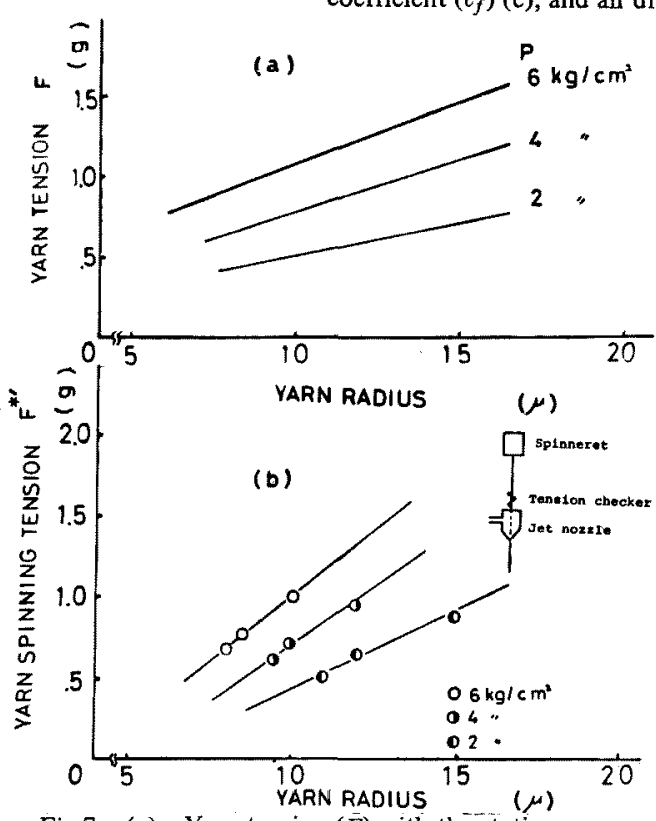

Fig.7 (a) Yarn tension $(\bar{F})$ with the stationary yarn measured by a strain gauge as in Fig. 3

(b) Yarn tension $\left(F^{* \prime}\right)$ with the running yarn measured by a yarn tension checker as shown in Fig.7 (b)
值で測定されているのて，F*よりわずかに大きいはずで

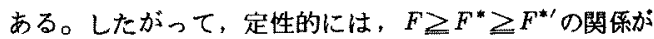
あると推定される。

$F, F^{* \prime}$ の実験結果をそれぞれFig. 7(a)(b)に示す。 $F$ ， $F^{*}$ の测定值は同様の傾向を示し, 織度の小さい所で $F$

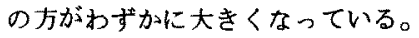

さて，2式に扔て，gの值は $T$ よりさらに小さいと 考えられるので， $T$ と同様 $g \div 0$ とすると， 2 式は， $F^{*}$ $=S+f$ となる。変形抗力 $S$ は, トルートン粘度と変形速 度勾配で与えられる。いま，高温にして紡条する場合， すなわちポリマーの変形抗力が無視されるほど小さくな った場合は、ジェット・ノズルよる張力と紡系孔から ジェット・ノズルまでの間の空気抵抗力がバランスし、 $F^{*} \div f$ として，延伸紐化が行なわれるようになる。この ような場合には，F*の代りにFと $f$ の曲線を重ね合わせ た状態で紡系が完了されると考えられる。Fig. 8の交点 は、ポリマーの変形抗力を無視できるほどの高温紡米し た場合の緉度を示し，この交点以下の織度は紡系できな いことを示している。この緎度を限界緎度とすると，そ の值は坧力 $(P)$ と紡夈孔からジェット・ノズルまでの距離 (L)の関数である。限界緎度の值をLに対して, 王力のパ ラメータでプロットすると, Fig.9のようになる。これよ ク，距離 $L$ と織度は，ほぼ直線関保にあり，王力が高い 


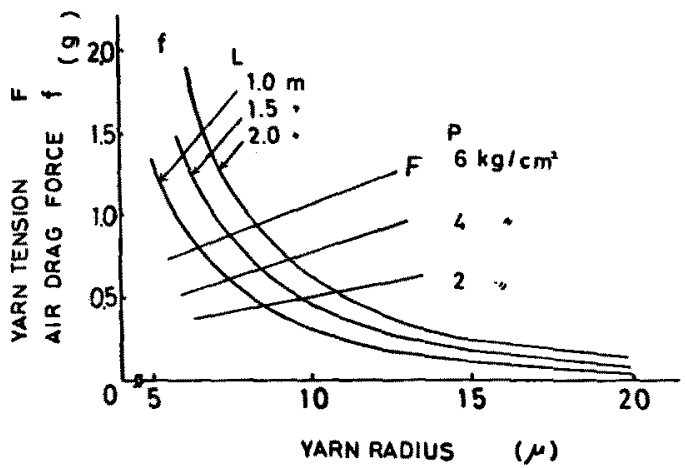

Fig. 8 The plots of yarn tension $(F)$ and air drag force $(f)$ against yarn radius $(R)$ in spinning. Each intersecting point shows the limiting value for the radius of the yam which can be drawn.

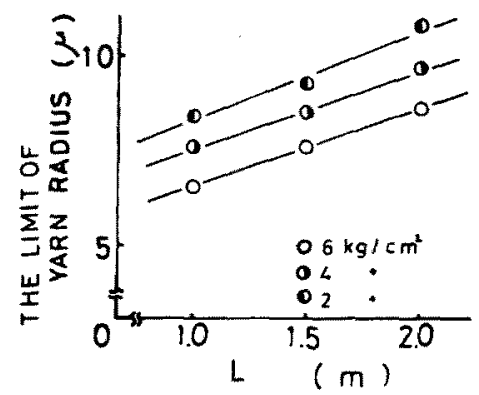

Fig. 9 The limiting values of yam fineness estimated from the distance $(L)$ between the spinneret and the air jet nozzle at various pressures $(P)$.

ほど，また距離しが小さいほど䋐度は小さくなることが わかる。これらの傾向について，奏駼的に娭討する。

\section{4. 実験結果および考察}

実験は，ボリプロピレン(チッソポリプロピレン，試 料番号 1016 , 固有粘度加ら求め大分子量的 81,000)を 試料として，紡系鼬度を $220 \sim 312^{\circ} \mathrm{C}$ の籍用て，加な 高盜の領域安で行なった。昍出量は， $0.485 \mathrm{~g} / \mathrm{min}$ ： $x \rightarrow+・ ノ$ スルの理力は, $2,4,6 \mathrm{~kg} / \mathrm{cm}^{2}$, 紡禹孔か 5

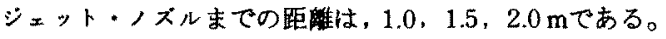

\section{1 度}

紡系温度と紡系された織維の織度を Fig.10に示す。 これより、紡米温度を七げてポりマーの変形抗力が小さ くなった場合，鐵度は小さくなるが，限框があることが わかる。また，代力は高いほど織度は小さくなる。つぎ に，王力と紡系速度の関係をFig.11に示す。紡系速度 は（3）式に轱度 $(R)$ の実澌值を代入して求めた。これ
より，速度は区加によって增加するが、紡禾温度が低い 場合に注变形抗力が大きくなり，速度はわずかしか增加 していないことがわかる。

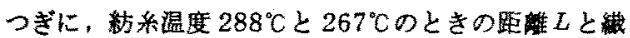
度の関係をFig.12(a)（b)に示す。これより，(a)(b)と もに距離 $L$ 之織度沬活ぼ直線威係にあり，臣方が高いほ ぞまたしは小さいほど（シェット・ノズを紡系孔に 近づけるほど) 轼度估小さくなることがわかる。これら の㮌向は，前速の推定と一致して拉り，推定値と実験值 を表にまとめると, Table 1のよ5になる。Table1の

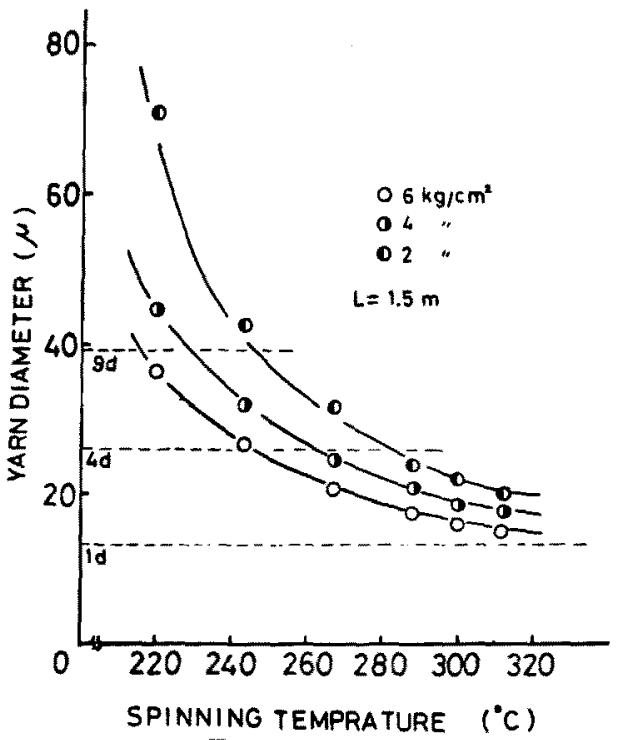

Fig. 10 The diameters of the yarn spun at various spinning temperatures.

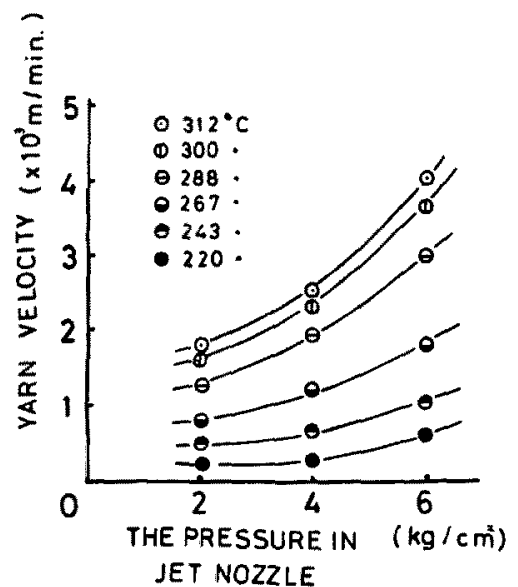

Fig. 11 The change of yarn velocity at different nozzle pressures and spinning temperatures 
Table 1 The experimental values of yarn radii at various temperatures and the limiting values estimated from $F$ and $F^{* \prime}$.

\begin{tabular}{|c|c|c|c|c|c|c|c|}
\hline \multirow{3}{*}{$\begin{array}{c}L \\
(\mathbf{m})\end{array}$} & \multirow{3}{*}{$\begin{array}{c}P \\
\left(\mathrm{~kg} / \mathrm{cm}^{3}\right)\end{array}$} & \multicolumn{4}{|c|}{ Spinning Temp. $\left({ }^{\circ} \mathrm{C}\right)$} & \multirow{2}{*}{\multicolumn{2}{|c|}{$\begin{array}{l}\text { The Limit of } \\
\text { Yarn Radii }\end{array}$}} \\
\hline & & 267 & 288 & 300 & 312 & & \\
\hline & & \multicolumn{4}{|c|}{ Yarn Radii $(\mu)$} & $F$ & $F^{* \prime}$ \\
\hline \multirow{3}{*}{1.0} & 6 & 8.8 & 7.6 & & & 6.6 & $(7.5)$ \\
\hline & 4 & 9.7 & 8.1 & & & 7.5 & $(8.2)$ \\
\hline & 2 & 12.3 & 9.1 & & & 8.3 & $(8.8)$ \\
\hline \multirow{3}{*}{1.5} & 6 & 10.3 & 8.3 & 8.1 & 7.6 & 7.6 & $(8.3)$ \\
\hline & 4 & 11.5 & 9.2 & 9.0 & 8.8 & 8.5 & $(9.1)$ \\
\hline & 2 & 14.2 & 10.8 & 10.3 & 10.0 & 9.5 & $(9.7)$ \\
\hline \multirow{3}{*}{2.0} & 6 & 11.8 & 8.6 & & & 8.5 & $(9.5)$ \\
\hline & 4 & 12.8 & 10.4 & & & 9.7 & (10.5) \\
\hline & 2 & 15.3 & 12.3 & & & 10.8 & $(11.1)$ \\
\hline
\end{tabular}

As the spinning temperature increases, the values of the yarn radii approach to the limiting values.
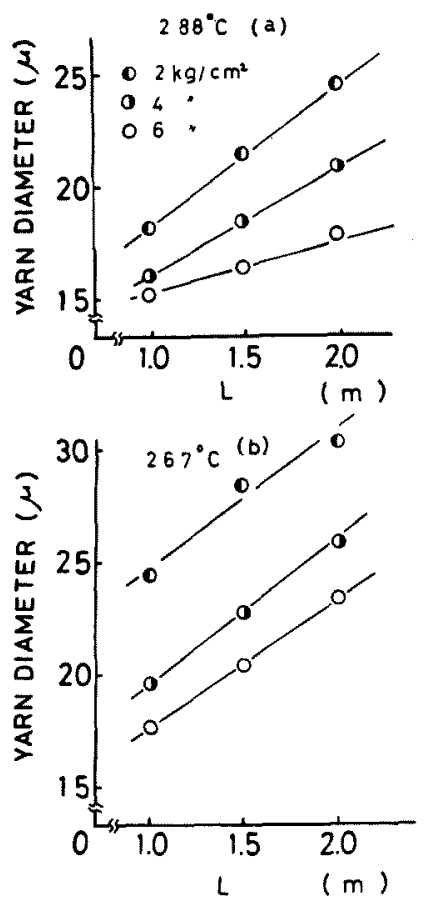

Fig. 12 The yarn diameters measured at various distance $(L)$ between the spinneret and the jet nozzle with different nozzle pressures.

限界緎度の值は，Fと $F^{* \prime} の$ 両万の测定結果より求めた

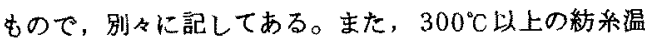
度のときの紻度ものせてある。これより，紡系温度が高 漏になりポリマーの変形抗力が小さくなるにつれて, 紡 緼度仕限界織度に近づき，紡类温度 $300^{\circ} \mathrm{C}$ 以上では， ほぼ限界值に達していることがわかる。

\section{2 強 伸 度}

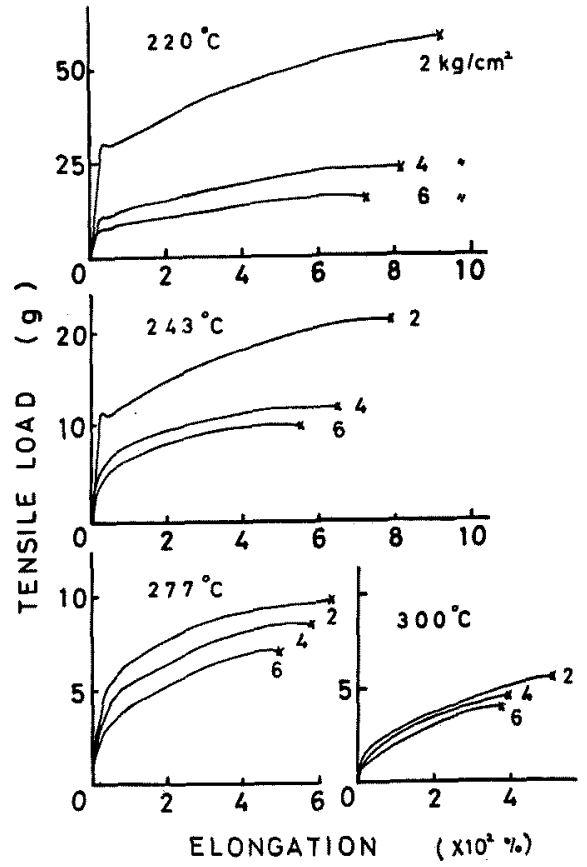

Fig.13 Several examples showing the tensile loadelongation curves at different temperatures and nozzle pressures.

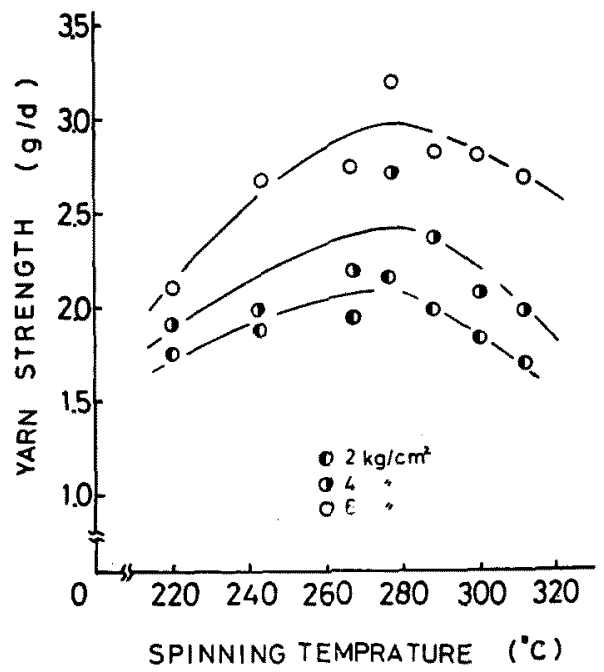

Fig.14 The strength $(\mathrm{g} / \mathrm{d})$ of yarn spun at various spinning temperatures with different nozzle pressures.

各紡系温度で紡系された試料の代表的な強伸度曲線を Fig. 13 に示す。この結果より紡䋆温度 $220^{\circ} \mathrm{C}, 243^{\circ} \mathrm{C}$ の試料では，ネッキングの現象がみられる。つぎに、紡 


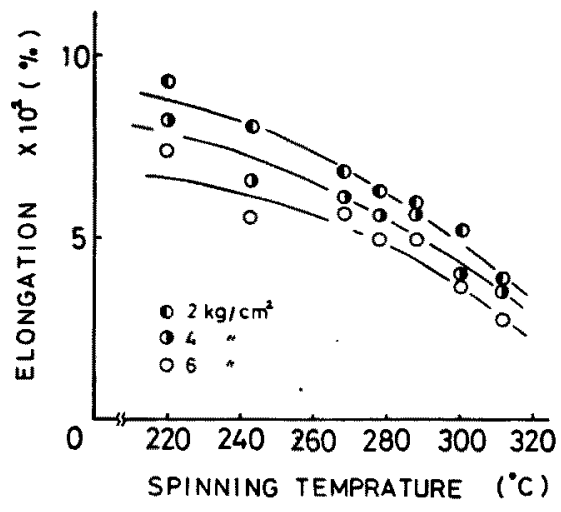

Fig. 15 The elongation (\%) of each yam.

系温度と強度 $(\mathrm{g} / \mathrm{d})$ を王力のパラメータでFig.14に示 す。これより，王力が高いほど強度は高く，紡米温度に 対しては，270〜 $280^{\circ} \mathrm{C}$ のき，最も端度は高くなり， $300^{\circ} \mathrm{C}$ 以上で減少している。これは，分子量の低下に 起因していると考えられるが，この点については，さら に鲜紐な検討が必要である。紡来温度と伸度の関原を Fig.15に示す。これより，紡系温度を上げるほど、また 王力が高いほと伸度は堿少することがわかる。ジェット ・ハズル位瑱を変えたときの強伸度の結果をFig.16に

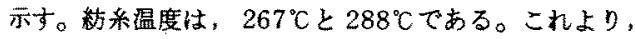
強度（g/d)は，距離 Lにほとんど関底しないが，伸度は 距䊒しが大きくなるとわずかに增加することがわかる。

4.3 複屈折

各陚料の複屈折をFig.17に示す。これより，王力が高

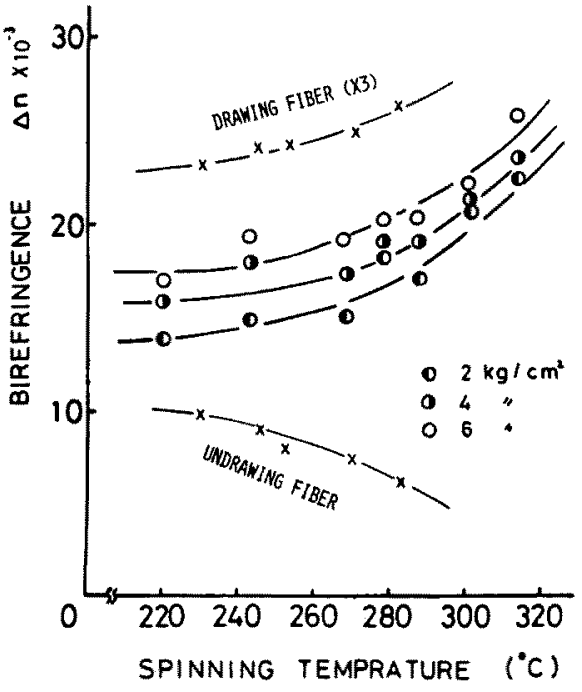

Fig. 17 The birefringence $(\Delta n)$ of each yarn.

いほど，また紡系温度が商いほど复屈折は增加する傾向 がみられ，これは同一試料により紡系された 3 倍延伸系 の傾向上一致している。シェット・ノズによる延伸采 の複屈折の値は，3 倍延伸系の值よりも低いが，末延伸 系の値よりもはるかに大きいことがわかる。

紡系温度 $267^{\circ} \mathrm{C}$ と $288^{\circ} \mathrm{C}$ の試料について, 轿度と複屈 折の関係を距離 $L$ 関数で, Fig. 18 (a)(b)に示す。

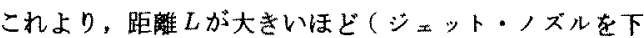
勿するほど）複屈折は大きくなることがわかる。これ

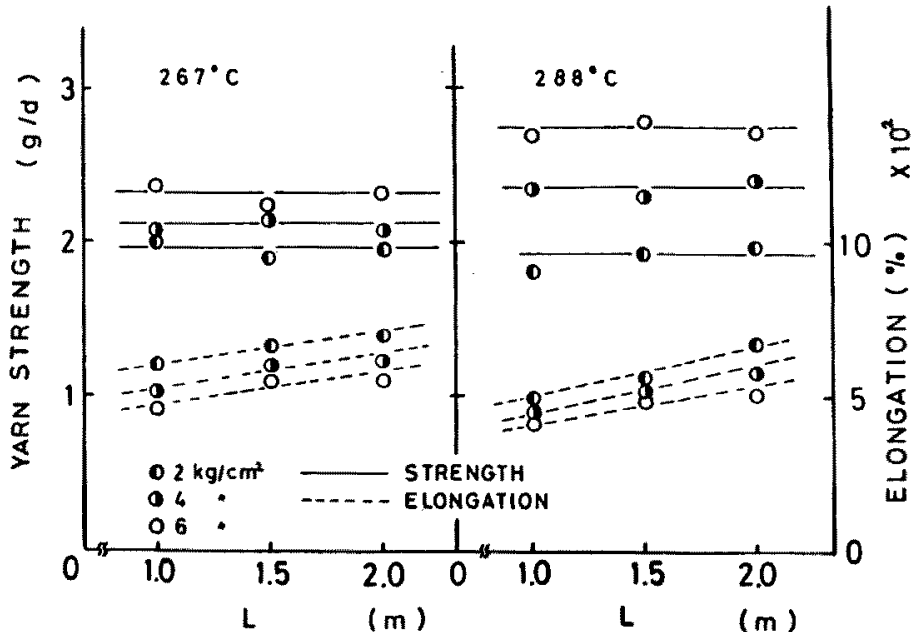

Fig. 16 The yarn strength and elongation plotted against the distance $(L)$ at various pressures $(P)$.
に関しては、詳細な换楌を必要と し速断できないが，溶融点以後の 結晶化の影響を受けるものと思わ れる。

\section{5. 結言}

シェット・ノズルを用いて、ポ リプロピレンの溶融紡系を行なっ た結果、つぎのことが明らかにな った。

(1) ジェット・ノスルの王力が, $2.18 \mathrm{~kg} / \mathrm{cm}^{2}$ 以上になると、シェ ット気流は音速に達し，紡系張力 に寄与寸るの性，衝㲎縞の锥察さ れる長さの範国内である。

（2）秒采速度は，ジェット现や 浴䗝温度をかなり上げても，シェ ット気流の $1 / 4 \sim 1 / 5$ 度である。 

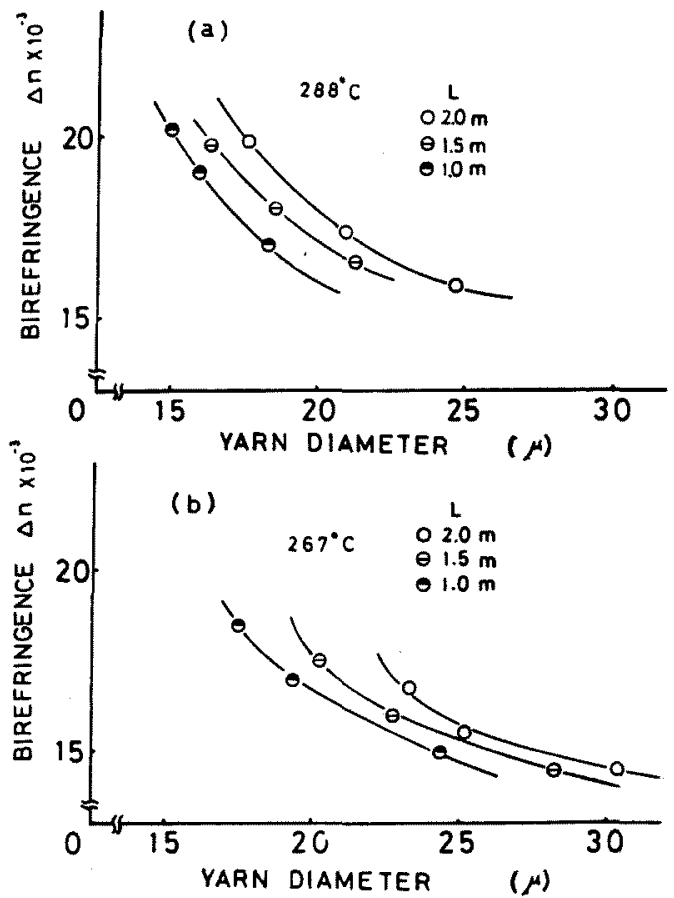

Fig. 18 Plots of birefringence $(\Delta n)$ against yarn diameter at spinning temperatures.

(a) $288^{\circ} \mathrm{C}$ (b) $267^{\circ} \mathrm{C}$
（3）当然のことながら, 紀系温度が高いほど,ポリマ 一の変形轨力が小さくなって，細い㵶維を紡系すること ができる。しかし，空気抵抗力と送り出し㲀力とのバ ンスから，紡采織度に限界がある。したがって，さらに 織度を下げるためには，何らかの方法で空気抵抗力を下 げる必要がある。

（4）紡系温度の距離 $L$ と王力 $P$ に対する㑯向は, 計算 の頋向とよく一致する。

（5）ジット・ノズルの位置が，紡系孔に近いほど， 紡禾される織維の㵶度は小さくなるが，䙡屈折は遠いは ど，大きくなる傾向がある。

（6）強度 $(\mathrm{g} / \mathrm{d})$ は，紡系温度が $270 \sim 280^{\circ} \mathrm{C} の と き ，$ 最高值をとり，伸度は紡系温度が高いほど小さくなった。

（7）複屈折は, 紡系温度が高いほど增加する侕问がみ られ，最高で約 $2.5 \times 10^{-2}$ であった。

以上の実験を進めるために種々御協力を睗った，東京 工業大学清水研究室岛崎佰蔵氏ならびに試料につき御便 宜を載いたチッソ株式会社に感謝します。

\section{文献}

1) 絨維学会編；㵶維の形成と構造の発見（化学同人, 1969)

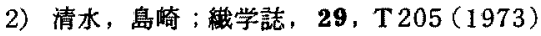

3）金綱，栗田；䄉高研究発表会参考資料， 153 (1972)

4）白倉，大倉；流体力学 (2)（コロナ社） 